\title{
Molecular Biological Studies on the Effect of the Electromagnetic Fields on ETS-1 Oncogene
}

\author{
Amany A. Tohamy*; Mohammed H. Awwad**; Nahed M. El-Abiad*** and \\ Abdel-Monsef A. Elhadary*** \\ *Department of Zoology, Faculty of Science, Helwan University, Egypt. \\ **Department of Zoology, Faculty of Science, Benha University, Egypt. \\ ***Biological Application Department, Nuclear Research center, Atomic Energy \\ Authority, Cairo, Egypt.
}

\begin{abstract}
ETS-1 is the founding member of the ETS family of transcription factors. ETS factors have important roles in oncogenesis, signal transduction and development. In human tumors, ETS-1 is expressed in endothelial cells and fibroblasts of the tumor stroma and is proposed to play a role in tumor vascularization and invasion by upregulating expression of matrixdegrading proteases. In human carcinomas, ETS-1 is also expressed by neoplastic cells, but little is known about the functional implications of this observation. The present study aimed to detect the tumor by using electromagnetic fields through ETS-1 oncogene. The detection of point mutations correlated with diseases is currently performed by digestion of PCR products (PCR/RFLP) by using restriction endonucleases. It has been described here a method based modified on primers during the PCR, and using some restriction endonucleases (AatI, BanI, BanII, DraI, DraIII, EaeI, PstI and SacII) which create a restriction fragment length polymorphism (RFLP) indicative of the studied mutation. The present study used the electromagnetic fields $(4.5 \mathrm{~Hz})$; PCR/RFLPs technique was selected as a biomarker to evaluate the effect of exposure to electromagnetic fields in implanted Ehrlich tumor of female BALB/C mice. Eighty mice were used and divided into four groups (20 each); normal, exposed (exposed to $4.5 \mathrm{~Hz}$ ), infected (normal infected by Ehrlich tumor) and infected exposed (infected exposed to $4.5 \mathrm{~Hz})$. DNA genome was extracted and ETS-1 oncogene detected ( 4460 bp). AatI, BanII and EaeI restriction endonucleases did not differentiate between the PCR products (ETS-1 genes) of the four groups (normal, exposed, infected and infected exposed mice groups). DraIII, SacII, PstI, BanI and DraI differentiated between the four groups. The results proved that the electromagnetic fields could treat the tumor and PCRIRFLPs were able to be a useful diagnostic technique.
\end{abstract}

Key words: electromagnetic field, cancer, ETS-1 oncogene, PCR/RFLP.

\section{Introduction}

Studies of electromagnetic field effects on cells have been carried out in three major domains of high, low, and extremely low electromagnetic fields. The application of high-pulsed electromagnetic fields to cells has been associated mostly with the phenomenon of electroporation (Neumann and Rosenheck, 1972; Zimmermann et al., 1974 and Kinosita and Tsong, 1977). Its employment has gained wide use in the areas of cell biology and biotechnology, since it supplied an efficient physical tool to permeabilize cells by opening hydrophilic pathways in the cell membrane, through which molecules could diffuse along their electrochemical gradients (Teissie, 2002; Gehl, 2003 and Weaver, 2003). Exposure of cells to extremely low electromagnetic fields has been associated with environmental exposures of humans to low-frequency electromagnetic and also, with possible 
application of medical therapeutic devices (Lacy-Hulbert et al., 1998; Adair, 1999 and Ahlbom et al., 2001). The underlying mechanisms of these very weak electromagnetic fields are still ill understood and highly debated (Adair 1999; Weaver et al., 1999; 2000 and Foster, 2003). The intermediate domain of low electromagnetic fields has been routinely applied in electrophysiological studies of ion transport through channels. It was realized quite early that physiological electric fields in tissues are at the lower end of this range (Jaffe, 1966; Nuccitelli and Jaffe, 1974 and Borgens et al., 1977). These endogenous electric fields were associated with processes of development, regener-ation and wound healing (Nuccitelli, 2003).

ETS proteins comprise a family of transcription factors that share a unique DNA binding domain, the ETS domain (Ghysdael and Boureux, 1997; Sharrocks et al., 1997; Dittmer and Nordheim, 1998 and Graves and Petersen, 1998). The name "ETS" stems from a sequence that was detected in an avian erythroblastosis virus, E26, where it formed a transforming gene together with $\Delta \mathrm{gag}$ and $c-m y b$ (Nunn et al., 1983 and Blair and Athanasiou, 2000). The newly discovered sequence was called E26 transformation specific sequence or ETS. Later, a cellular homologue to the viral ETS $(v-E T S)$ gene, $c$-ETS-1, was found suggesting that $v$-ETS derived from $c$-ETS-1 (Watson et al., 1985 and Ghysdael et al., 1986).

The c-ETS- 1 protein is closely related to c-ETS-2. It is believed that these two proteins derived from the same ancestor gene by duplication (Lautenberger et al., 1992 and Albagli et al., 1994). In humans, the ETS- 1 and ETS-2 genes are located on two distinct chromosomes, ETS-1 on chromosome \#11, ETS-2 on chromosome \#21 (Watson et al., 1985).

ETS-1 is produced by a variety of solid tumors, including epithelial tumors, sarcomas and astrocytomas. Depending on the tumor type, ETS-1 expression is either increased or exclusively found in invasive higher grade tumors. High ETS-1 levels in breast, ovarian and cervical carcinoma correlate with poorer prognosis (Davidson et al., 2001; Fujimoto et al., 2002; Span et al., 2002 and Takai et al., 2002). ETS-1 was found to be an independent prognostic marker of breast cancer that was not linked to other tumor markers, such as nodal status, tumor size, histological grade or estrogen receptor status (Span et al., 2002). In lung, colorectal and squamous cell carcinoma, ETS-1 expression was associated with a higher incidence of lymph node metastasis (Pande et al., 1999; Saki et al., 2001 and Tokuhara et al., 2003). In endometrial and ovarian cancer, the presence of ETS-1 correlated with a higher histological grade (Takai et al., 2000 and Takai et al., 2002). In addition to advanced solid tumors, high ETS-1 expression has also been found in leukemic T-cells (Sacchi et al., 1988).

ETS genes are transcription factors expressed in different tissues. Biochemical pathways interfering with the intracellular calcium ion concentration are known to influence members of this gene family. Considering experimental observations and previous reports, Romano-Spica and Mucci (2003) proposed a hypothetical model of interaction between EMF and ETS, based on possible interference in pathways involving calcium as a second messenger. Mucci et al. (2001) and Romano-Spica et al. (2000) observed an increase in ETS-1, mRNA and protein expression, but a decrease in ETS-2 protein levels when the rat was exposed to the electromagnetic field.

Several techniques were observed the mutations of ETS-1 gene and its expressions such as; Western blot ( $\mathrm{Lu}$ et al., 2004), GeneChip (Deneen et al., 2003) and Restriction Fragment Length Polymorphisms (Kerckaert et al., 1989).

To further understand the effect of electromagnetic fields on tumors and also, to effectively diagnose them, the present study endeavored to determine the electromagnetic field effect on ETS-1 oncogene of normal, exposed (normal mice exposed to EMF), infected (implanted Ehrlich tumor) and infected exposed mice (infected mice exposed to EMF) digesting them by certain restriction endonucleases. 


\section{Material And Methods}

Animals and animal husbandry: Four groups of female $\mathrm{BALB} / \mathrm{C}$ mice $(20$ mice each; 16-20 g) were used and housed at The National Cancer Institute, Cairo University, Egypt. The four groups of experimental mice were grouped as; 20 normal mice, 20 exposed mice (normal mice exposed to electromagnetic field), 20 infected mice (implanted Ehrlich tumor) and 20 infected exposed mice (implanted Ehrlich tumor exposed to electromagnetic field). The third and fourth mice groups were injected at their thigh region by $0.2 \mathrm{ml}$ each of $1 \times 10$ single cell $/ \mathrm{ml}$ suspension isolated from Ehrlich ascites carcinomas.

Exposure setup: The whole mice were fixed alive between two electrodes. The experimental mice were exposed to $4.5 \mathrm{~Hz}$ amplitude modulated square waves form and the wave carrier frequency was 10 MHz. The exposure started on the $10^{\text {th }}$ day of injection and extended for 21 days. The duration of exposure was for two hours every two days. Electromagnetic field exposure includes group 2 and group 4. At the end of the twenty first day of exposure, the tumor size of the exposed infected group reduced.

DNA extraction: One gram from each sample of the four groups was homogenized in $500 \mu 1$ of isotonic solution and centrifuged at 5,000 rpm for 5 minutes. The cell pellet was resuspended in $500 \mu \mathrm{l}$ of UNSET (Lysis solution; 8M urea, 2\% sodium dodecyl sulfate, $0.15 \mathrm{M} \mathrm{NaCl}$, 0.001M EDTA, 0.1M Tris pH 7.5); (Hugo et al., 1992 and Awwad 2003). Phenolchloroform extraction was used two to three times to separate the organic and aqueous phases. To precipitate the nucleic acid, iced absolute ethanol was added $(2: 1 \mathrm{v} / \mathrm{v})$, and left to incubate at $-20^{\circ} \mathrm{C}$ for 24 to 48 hours. The nucleic acids were recovered by centrifugation at $\sim 5,000 \mathrm{rpm}$ for 15 minutes. The pellet was dried and then resuspended in $40 \mu \mathrm{l}$ of sterile $\mathrm{H}_{2} \mathrm{O}$. One $\mu \mathrm{l}$ of the resuspended pellet was checked by agarose gel electrophoresis for the presence of DNA ( figure 1).
ETS-1 oncogene detection: To amplify the complete ETS- 1 gene, one $\mu 1$ of whole-cell DNA template was used in addition to oligonucleotide primers complementary either to the 5 and 3 ends of the gene (ETS-1:a 5'-ACCCAGAT GAGGTGGCCAGGAGATG-3' and ETS-1:b 5'AGCCCCTTCAGTGCCATCAC TCGTC$3 '$ ). The standard PCR reaction mixture was used (Kessing et al., 1989). The standard polymerase chain reaction program for amplification of ETS-1 oncogene was: 3540 cycles; one minute, at $94^{\circ} \mathrm{C}$; two to three minutes, at $45^{\circ} \mathrm{C}$; and three minutes, at $65^{\circ} \mathrm{C}$. Deoxynucleotide triphosphates (dNTP, dATP, dGTP, dTTP, and dCTP) were from Perkin Elmer Cetus, USA. The taq DNA polymerase used for ETS-1 gene amplification was from Boehringer Mannheim Biochemica (Germany) and Gibco/BRL (Gaithersburg, Md., USA). One $\mu l$ of the PCR products was checked by gel electrophoresis for the presence of ETS-1 gene size ( 4460 bp) .

Restriction fragment length polymorphisms (RFLPS): Several restriction enzymes were used in this study; these are AatI (Toyobo Biochemicals); BanI, BanII, DraI, DraIII and EaeI (BoehringerMannheim) and PstI and SacII (Sigma). Restriction endonucleases were used to digest the ETS-1 gene of the four groups. Digestion and RFLP analysis were performed as described by Vidigal et al. (1998).

\section{Results}

ETS-1 oncogenes were obtained for normal, exposed, infected and infected exposed groups from the PCR products. The sizes of ETS-1 genes were approximately 4460 bp (Fig. 2).

AatI, BanII and EaeI restriction endonucleases did not clarify the differences between the normal, exposed, infected and infected exposure mice ETS-1 oncogene. AatI restriction enzyme cut the four mice gene groups into three restriction fragments $(\sim 140, \sim 570$ and $\sim 3750 \mathrm{bp}$, Fig. 3 and Table 1). ETS-1 oncogene of the four 
groups digested into four digested fragments $(\sim 320, \sim 730, \sim 1470$ and $\sim 1940$ bp) when treated with BanII restriction endonuclease (Fig. 4 and Table 2). Also, EaeI restriction enzyme restricted the ETS1 gene into four restriction fragments $(\sim 330, \sim 710, \sim 1540$ and $\sim 1880$ bp; Fig. 5 and Table 3) but into different sizes than BanII restriction enzyme when digesting the same gene.

DraIII and SacII restriction endonucleases clustered the gene of the normal group in one cluster and the gene of the other three groups in another. DraIII enzyme digested ETS-1 oncogene of the normal group into two restriction fragments ( 670 and $\sim 3790$ bp; Fig. 6, lane 1 and Table 4) while cut the exposed, infected and infected exposed gene into three restriction bands $(\sim 670, \sim 1500$ and $\sim 2290$ bp; Fig. 6, lanes 2, 3 and 4 and Table 4). Also, SacII restriction endonuclease fragmented the normal ETS-1 oncogene into two bands ( 2030 and $\sim 2430$ bp; Fig. 7, lane 1 and Table 5) whenever the same restriction enzyme digested the gene of the exposed, infected and infected exposed into four restriction fragments $(\sim 500, \sim 730$, $\sim 1500$ and $\sim 1730$ bp; Fig. 7, lanes 2, 3 and 4 and Table 5).

PstI restriction enzyme differentiated the oncogene of the four groups into two groups; the gene of normal and exposed mice in one group and the other two in another group (Fig. 8 and Table 6). PstI restriction endonuclease digested the gene of normal and exposed gene into four bands $(\sim 130, \sim 710, \sim 1410$ and $\sim 2210 \mathrm{bp}$; lanes 1 and 2) whereas it cut the gene of infected and infected exposed gene of mice into five restriction bands $(\sim 130, \sim 500, \sim 710, \sim 1410$ and $\sim 1710 \mathrm{bp}$; lanes 3 and 4 ).

Three clusters were differentiated when BanI restriction enzyme digested their gene (Fig. 9 and Table 7). BanI restriction endonuclease digested the oncogene of normal and exposed mice into three cuts ( 740, 1160 and $~ 2560 \mathrm{bp}$; lanes 1 and 2$)$ while it digested the gene of infected mice into five restriction fragments $(\sim 300, \sim 440$, $\sim 1000, \sim 1160$ and $\sim 1560 \mathrm{bp}$; lane 3 ) and infected exposed mice into four bands ( 300, 440, 1160 and 2560 bp; lane 4).

DraI restriction endonuclease differentiated between ETS-1 oncogene of the four groups (Fig. 10 and Table 8). ETS1 gene of the normal mice was digested into two fragments ( 100 and $\sim 4360 \mathrm{bp}$; lane 1) when treated with DraI enzyme. DraI restriction fragment digested the gene of exposed mice into three fragments $(\sim 100$, $\sim 1600$ and $\sim 2760 \mathrm{bp}$; lane 2). The same restriction endonuclease cut the oncogene of infected mice into five bands $(\sim 100$, $\sim 600, \sim 1000, \sim 1200$ and $\sim 1560 \mathrm{bp}$; lane 3) and the gene of infected exposed mice into four restriction fragments $(\sim 100, \sim 600$, $\sim 1000$ and $\sim 2760 \mathrm{bp}$; lane 4).

Table 1: Length of ETS-1 oncogene fragments, resulting from digestion with AatI enzyme of the normal,exposed, infected and infected exposed groups. (see Fig. 3)

\begin{tabular}{|c|c|c|c|c|c|c|}
\hline Groups & Band \#1 & Band \#2 & Band \#3 & Band \#4 & Band \#5 & Band \#6 \\
\hline Normal & $\sim 140$ & $\sim 570$ & $\sim 3750$ & $\ldots \ldots$ & $\ldots \ldots$ & $\ldots \ldots$ \\
\hline Exposed & $\sim 140$ & $\sim 570$ & $\sim 3750$ & $\ldots \ldots$ & $\ldots \ldots$ & $\ldots \ldots$ \\
\hline Infected & $\sim 140$ & $\sim 570$ & $\sim 3750$ & $\ldots \ldots$ & $\ldots \ldots$ & $\ldots \ldots$ \\
\hline Infected Exposed & $\sim 140$ & $\sim 570$ & $\sim 3750$ & $\ldots \ldots$ & $\ldots \ldots$ & $\ldots \ldots$ \\
\hline
\end{tabular}

Table 2: Length of ETS-1 gene fragments, resulting from digestion with BanII enzyme of the normal,exposed, infected and infected exposed groups. (see Fig. 4)

\begin{tabular}{|l|l|l|l|l|l|l|}
\hline Groups & Band \#1 & Band \#2 & Band \#3 & Band \#4 & Band \#5 & Band \#6 \\
\hline Normal & $\sim 320$ & $\sim 730$ & $\sim 1470$ & $\sim 1940$ & $\ldots \ldots$ & $\ldots \ldots$ \\
\hline Exposed & $\sim 320$ & $\sim 730$ & $\sim 1470$ & $\sim 1940$ & $\ldots \ldots$ & $\ldots \ldots$ \\
\hline Infected & $\sim 320$ & $\sim 730$ & $\sim 1470$ & $\sim 1940$ & $\ldots \ldots$ & $\ldots \ldots$ \\
\hline Infected Exposed & $\sim 320$ & $\sim 730$ & $\sim 1470$ & $\sim 1940$ & $\ldots \ldots$ & $\ldots \ldots$ \\
\hline
\end{tabular}


Table 3: Length of ETS-1 gene fragments, resulting from digestion with EaeI enzyme of the normal, exposed, infected and infected exposed groups. (see Fig. 5)

\begin{tabular}{|l|l|l|l|l|l|l|}
\hline Groups & Band \#1 & Band \#2 & Band \#3 & Band \#4 & Band \#5 & Band \#6 \\
\hline Normal & $\sim 330$ & $\sim 710$ & $\sim 1540$ & $\sim 1880$ & $\ldots \ldots$ & $\ldots \ldots$ \\
\hline Exposed & $\sim 330$ & $\sim 710$ & $\sim 1540$ & $\sim 1880$ & $\ldots \ldots$ & $\ldots \ldots$ \\
\hline Infected & $\sim 330$ & $\sim 710$ & $\sim 1540$ & $\sim 1880$ & $\ldots \ldots$ & $\ldots \ldots$ \\
\hline Infected Exposed & $\sim 330$ & $\sim 710$ & $\sim 1540$ & $\sim 1880$ & $\ldots \ldots$ & $\ldots \ldots$ \\
\hline
\end{tabular}

Table 4: Length of ETS-1 gene fragments, resulting from digestion with DraIII enzyme of the normal ,exposed, infected and infected exposed groups. (see Fig. 6)

\begin{tabular}{|l|l|l|l|l|l|l|}
\hline Groups & Band \#1 & Band \#2 & Band \#3 & Band \#4 & Band \#5 & Band \#6 \\
\hline Normal & $\sim 670$ & $\sim 3790$ & $\ldots \ldots$ & $\ldots \ldots$ & $\ldots \ldots$ & $\ldots \ldots$ \\
\hline Exposed & $\sim 670$ & $\sim 1500$ & $\sim 2290$ & $\ldots \ldots$ & $\ldots \ldots$ & $\ldots \ldots$ \\
\hline Infected & $\sim 670$ & $\sim 1500$ & $\sim 2290$ & $\ldots \ldots$ & $\ldots \ldots$ & $\ldots \ldots$ \\
\hline Infected Exposed & $\sim 670$ & $\sim 1500$ & $\sim 2290$ & $\ldots \ldots$ & $\ldots \ldots$ & $\ldots \ldots$ \\
\hline
\end{tabular}

Table 5: Length of ETS-1 gene fragments, resulting from digestion with SacII enzyme of the normal, exposed, infected and infected exposed groups. (see Fig. 7)

\begin{tabular}{|l|l|l|l|l|l|l|}
\hline Groups & Band \#1 & Band \#2 & Band \#3 & Band \#4 & Band \#5 & Band \#6 \\
\hline Normal & $\sim 2030$ & $\sim 2430$ & $\ldots \ldots$ & $\ldots \ldots$ & $\ldots \ldots$ & $\ldots \ldots$ \\
\hline Exposed & $\sim 500$ & $\sim 730$ & $\sim 1500$ & $\sim 1730$ & $\ldots \ldots$ & $\ldots \ldots$ \\
\hline Infected & $\sim 500$ & $\sim 730$ & $\sim 1500$ & $\sim 1730$ & $\ldots \ldots$ & $\ldots \ldots$ \\
\hline Infected Exposed & $\sim 500$ & $\sim 730$ & $\sim 1500$ & $\sim 1730$ & $\ldots \ldots$ & $\ldots \ldots$ \\
\hline
\end{tabular}

Table 6: Length of ETS-1 gene fragments, resulting from digestion with PstI enzyme of the normal, exposed, infected and infected exposed groups. (see Fig. 8)

\begin{tabular}{|l|l|l|l|l|l|l|}
\hline Groups & Band \#1 & Band \#2 & Band \#3 & Band \#4 & Band \#5 & Band \#6 \\
\hline Normal & $\sim 130$ & $\sim 710$ & $\sim 1410$ & $\sim 2210$ & $\ldots \ldots$ & $\ldots \ldots$ \\
\hline Exposed & $\sim 130$ & $\sim 710$ & $\sim 1410$ & $\sim 2210$ & $\ldots \ldots$ & $\ldots \ldots$ \\
\hline Infected & $\sim 130$ & $\sim 500$ & $\sim 710$ & $\sim 1410$ & $\sim 1710$ & $\ldots \ldots$ \\
\hline Infected Exposed & $\sim 130$ & $\sim 500$ & $\sim 710$ & $\sim 1410$ & $\sim 1710$ & $\ldots \ldots$ \\
\hline
\end{tabular}

Table 7: Length of ETS-1 gene fragments, resulting from digestion with BanI enzyme of the normal, exposed, infected and infected exposed groups. (see Fig. 9)

\begin{tabular}{|l|l|l|l|l|l|l|}
\hline Groups & Band \#1 & Band \#2 & Band \#3 & Band \#4 & Band \#5 & Band \#6 \\
\hline Normal & $\sim 740$ & $\sim 1160$ & $\sim 2560$ & $\ldots \ldots$ & $\ldots \ldots$ & $\ldots \ldots$ \\
\hline Exposed & $\sim 740$ & $\sim 1160$ & $\sim 2560$ & $\ldots \ldots$ & $\ldots \ldots$ & $\ldots \ldots$ \\
\hline Infected & $\sim 300$ & $\sim 440$ & $\sim 1000$ & $\sim 1160$ & $\sim 1560$ & $\ldots \ldots$ \\
\hline Infected Exposed & $\sim 300$ & $\sim 440$ & $\sim 1160$ & $\sim 2560$ & $\ldots \ldots$ & $\ldots \ldots$ \\
\hline
\end{tabular}

Table 8: Length of ETS-1 gene fragments, resulting from digestion with DraI enzyme of the normal, exposed, infected and infected exposed groups. (see Fig. 10)

\begin{tabular}{|l|l|l|l|l|l|l|}
\hline Groups & Band \#1 & Band \#2 & Band \#3 & Band \#4 & Band \#5 & Band \#6 \\
\hline Normal & $\sim 100$ & $\sim 4360$ & $\ldots \ldots$ & $\ldots \ldots$ & $\ldots \ldots$ & $\ldots \ldots$ \\
\hline Exposed & $\sim 100$ & $\sim 1600$ & $\sim 2760$ & $\ldots \ldots$ & $\ldots \ldots$ & $\ldots \ldots$ \\
\hline Infected & $\sim 100$ & $\sim 600$ & $\sim 1000$ & $\sim 1200$ & $\sim 1560$ & $\ldots \ldots$ \\
\hline Infected Exposed & $\sim 100$ & $\sim 600$ & $\sim 1000$ & $\sim 2760$ & $\ldots \ldots$ & $\ldots \ldots$ \\
\hline
\end{tabular}




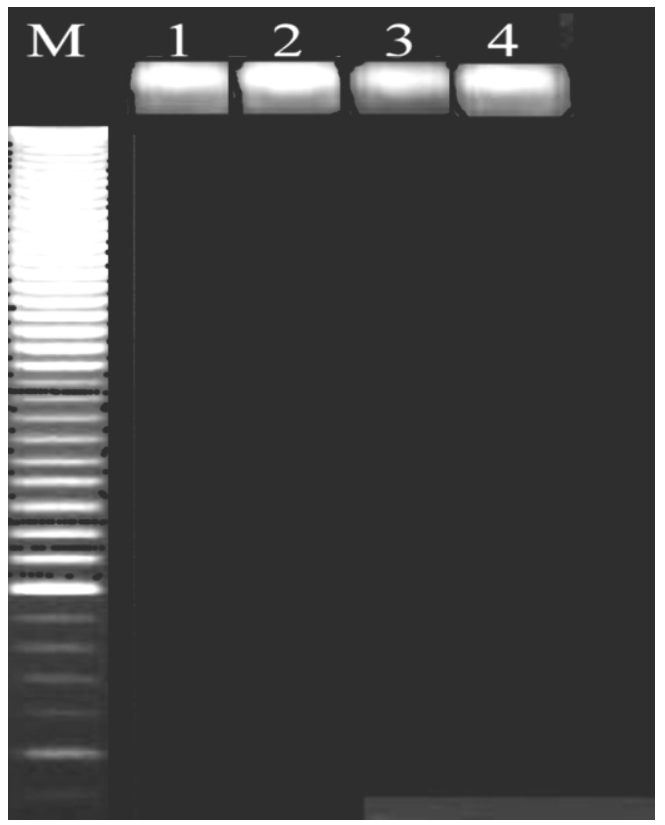

Fig. 1: DNA genome from normal, exposed, infected and infected exposed groups of mice. Lane $M$ is the DNA ladder (100-4000 bp). Lanes 1 represents the DNA genome of normal group and lanes 2-4 represent the exposed, infected and infected exposed groups of mice, respectively.

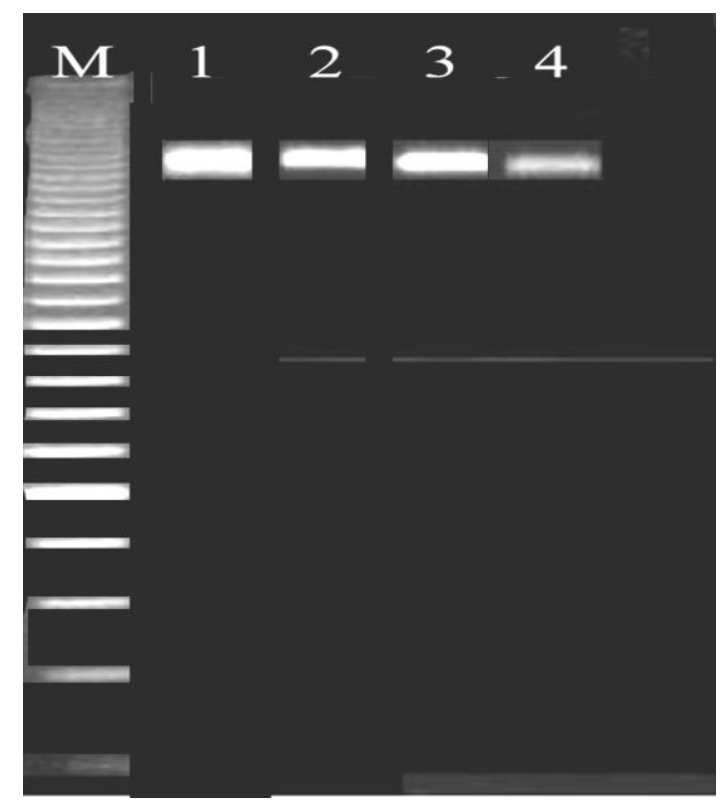

Fig. 2: Symbolized full-segment ETS-1 oncogene $(\sim 460 \mathrm{bp})$ of the normal and the other three treated groups. Lane $M$ is the DNA ladder (200-6000 bp). Lane 1 represents EST1 gene of the normal group of mice and lanes 2-4 represent the gene of the other three groups (exposed, infected and infected exposed, respectively). 


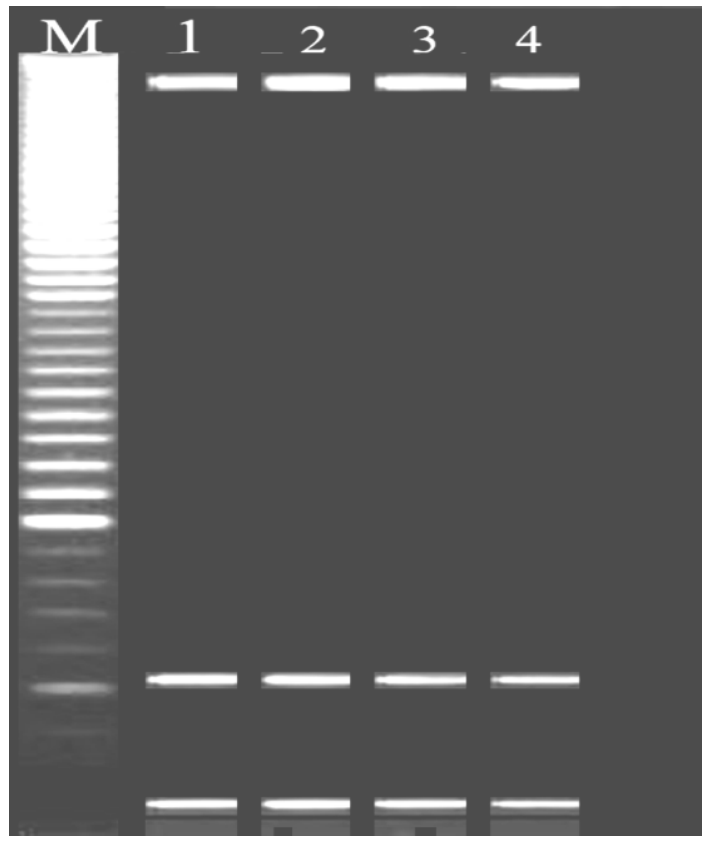

Fig. 3: Representative RFLPs patterns from the normal and the three groups with AatI restriction endonuclease, which produced roughly the same fragments (three bands; 140, 570 and $\sim 3750 \mathrm{bp}$, for all). Lane $M$ is DNA ladder (100-4000 bp).

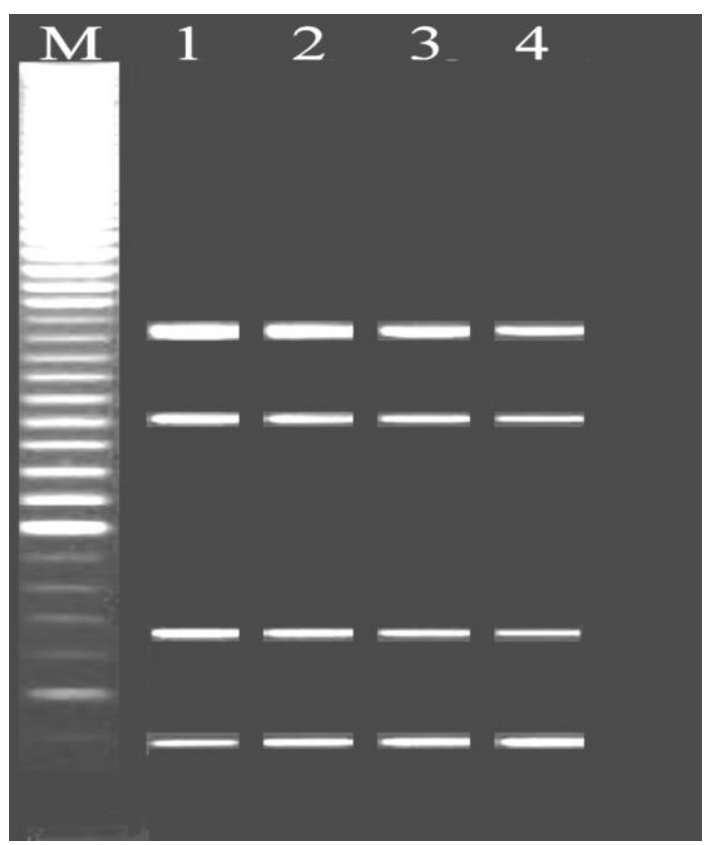

Fig. 4: Representative RFLPs patterns from the normal and the three groups with BanII restriction endonuclease, which produced roughly the same fragments (four bands; $\sim 320, \sim 730, \sim 1470$ and $\sim 1940 \mathrm{bp}$, for all). Lane $M$ is DNA ladder (100-4000 bp). 


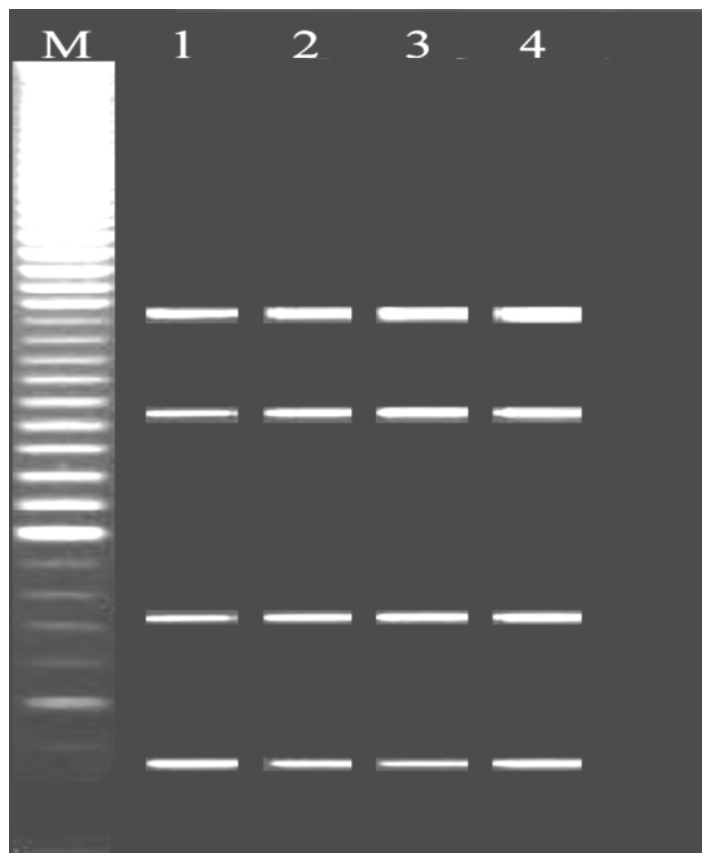

Fig. 5: Representative RFLPs patterns from the unexposed rats and three treated groups with EaeI restriction endonuclease, which produced roughly the same fragments (four bands; 330, 710, 1540 and 1880 bp, for all). Lane $M$ is DNA ladder (100$4000 \mathrm{bp})$.

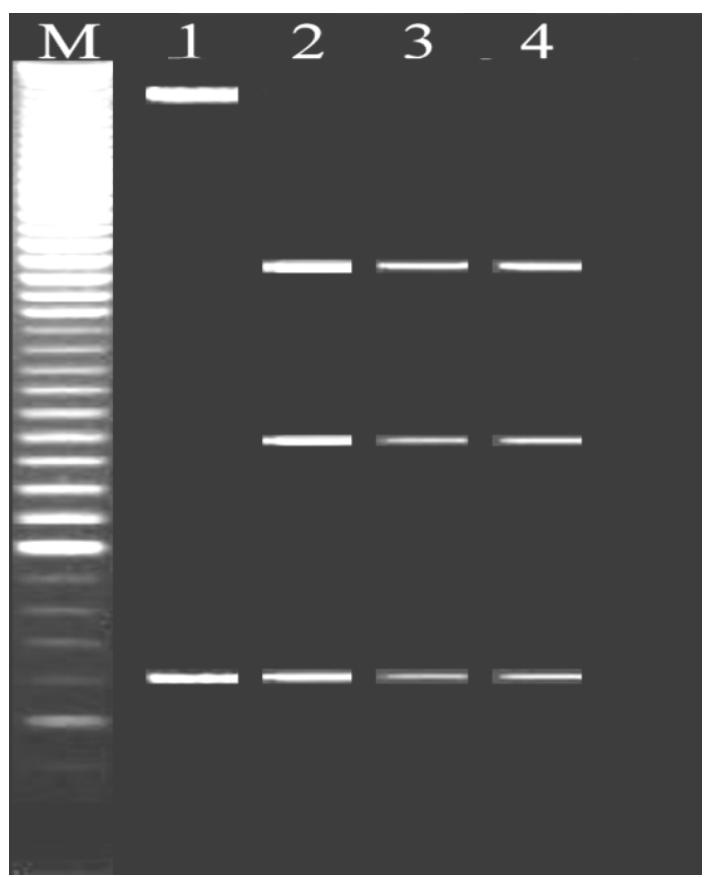

Fig. 6: Representative RFLPs patterns from the normal and the three treated groups with DraIII restriction endonuclease, which digested the gene of the normal group into two restriction fragments $(\sim 670$ and $\sim 3790 \mathrm{bp}$; lane 1$)$. Whereas, the gene of the other three groups (exposed, lane 2; infected, lane 3 and infected exposed, lane 4) were digested with the same enzyme into three restriction fragments $(\sim 670, \sim 1500$ and $\sim 2290 \mathrm{bp}$ ). Lane $M$ is DNA ladder (100-4000 bp). 


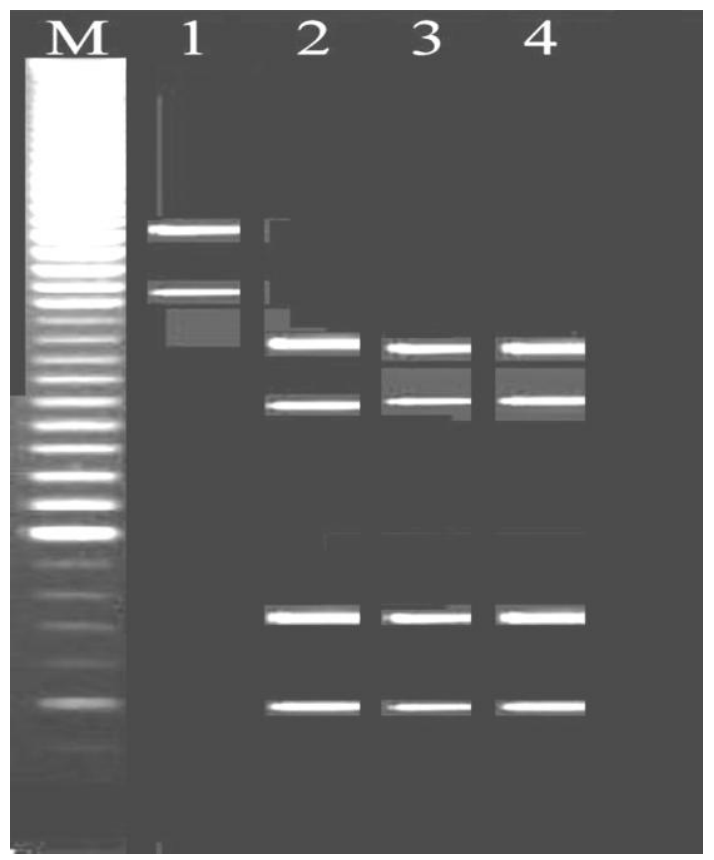

Fig. 7: SacII restriction enzyme digested the ETS-1 genes of the normal group into two cuts $(\sim 2030$ and $\sim 2430 \mathrm{bp}$; lane 1$)$. Whereas, the genes of the exposed, infected and infected exposed groups were digested with the same enzyme into four fragments ( 500, 730, 1500 and $\sim 1730$ bp; lanes 2,3 and 4).

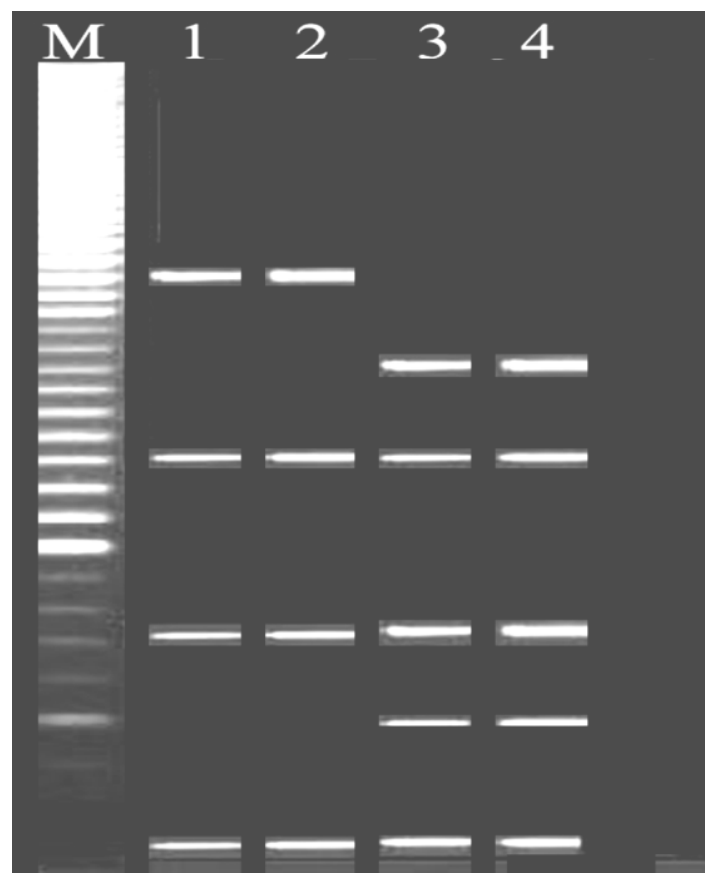

Fig. 8: PstI restriction enzyme digested the ETS-1 gene of the normal and exposed groups of mice into four cuts $(\sim 130, \sim 710, \sim 1410$ and $\sim 2210$ bp; lanes 1 and 2$)$. Whereas, the gene of infected and infected exposed groups were digested with the same enzyme into five fragments $(\sim 130, \sim 500, \sim 710, \sim 1410$ and $\sim 1710 \mathrm{bp}$; lanes 3 and 4$)$. Lane $M$ is DNA ladder (100-4000 bp). 


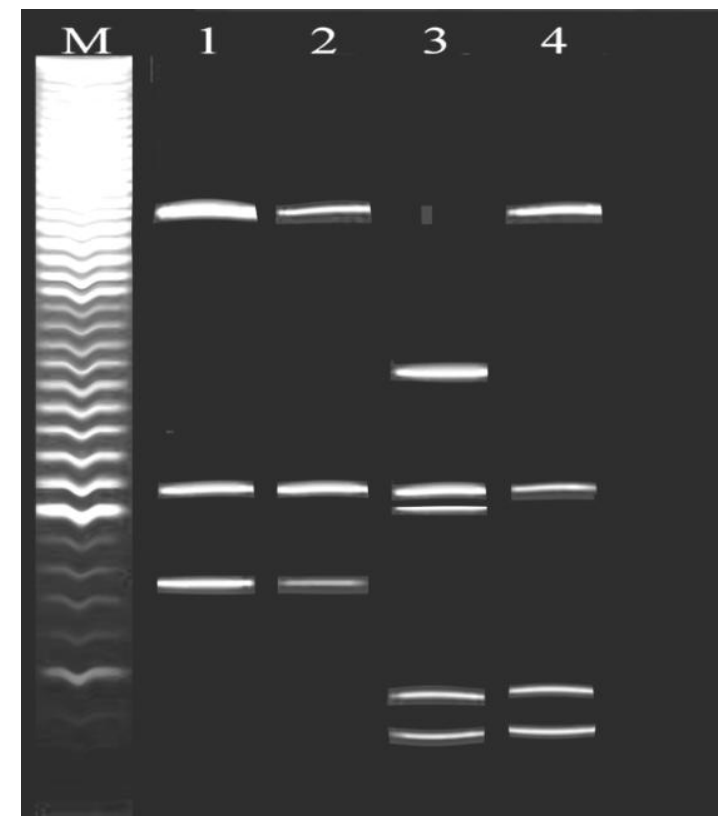

Fig. 9: BanI restriction enzyme digested the ETS-1 gene of the normal and exposed groups into three restriction cuts $(\sim 740, \sim 1160$ and $\sim 2560$ bp; lanes 1 and 2$)$. Whereas, the gene of infected group was digested with the same enzyme into five fragments $(\sim 300, \sim 440, \sim 1000, \sim 1160$ and $\sim 1560$ bp; lane 3). The same endonuclease fragmented the gene of infected exposed group into four fragments $(\sim 300, \sim 440$, $\sim 1160$ and $\sim 2560 \mathrm{bp}$; lane 4). Lane $M$ is DNA ladder (100-4000 bp).

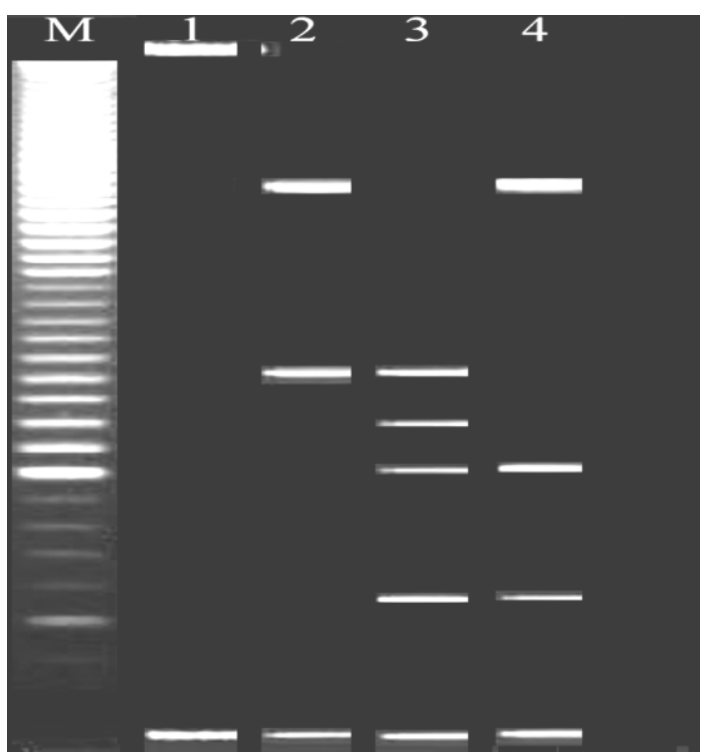

Fig. 10: DraI restriction enzyme digested the ETS-1 genes of the normal group into two cuts $(\sim 100$ and $\sim 4360 \mathrm{bp}$; lane 1$)$. Whereas, the gene of the exposed group was digested with the same enzyme into three fragments $(\sim 100, \sim 1600$ and $\sim 2760$ bp; lane 2). The same restriction endonuclease cut the oncogene of infected mice into five bands $(\sim 100, \sim 600, \sim 1000, \sim 1200$ and $\sim 1560 \mathrm{bp}$; lane 3$)$ and the gene of infected exposed mice into four restriction fragments $(\sim 100, \sim 600, \sim 1000$ and $\sim 2760 \mathrm{bp}$; lane 4).Lane $\mathrm{M}$ is DNA ladder (100-4000 bp). 


\section{Discussion}

The ETS family genes and their products have been implicated in several malignant diseases and pathological genetic disorders. For instance, ETS-1, ETS-2, and ERG have been shown to act as protooncogenes in that they can transform NIH 3 T3 cells in vitro, and the subsequent injection of these cells into nude mice results in tumor formation (Seth et al., 1989; Seth and Papas, 1990; Topol et al., 1992; Teitell et al., 1999 and Kawagoe et al., 2004). Furthermore, the FLI1 and ERG genes have been shown to be translocated and express chimeric fusion transcripts in almost all Ewing's sarcomas as well as in a large number of other primitive neuroectodermal tumors (Delattre et al., 1992; Sorensen et al., 1994 and Wang et al., 2005). Thus, these findings are strongly suggestive of a basic role for these genes in the genesis of these types of tumors. Recently, the overexpression of ETS-2 in transgenic mice has been shown to cause skeletal abnormalities phenotypically reminiscent of those seen in Down syndrome, in which ETS-2 genes are known to be present in triplicate (Sumarsono et al., 1996 and Rainis et al., 2005).

Several studies on ETS-1 gene treated with electromagnetic fields and waves may be of help in the treatment of cancer (Romano-Spica et al., 2000 and 2003). PCR/RFLPs profile of ETS-1 oncogene produced high variations between the normal, control, infected and infected exposure mice according to the differences of profiles obtained with the restriction endonucleases DraIII, SacII, PstI, BanI and DraI. On the other hand, the molecular results obtained with PCR/RFLP of ETS-1 gene suggested that AatI, BanII and EaeI restriction endonucleases did not clarify the differences between the normal, exposed, infected and infected exposure mice ETS-1 oncogene based on the similarity of profiles obtained with these restriction endonucleases.

The study may prove that the electromagnetic fields could mutate the mutated ETS-1 oncogene. In addition, the present study shows that the electromagnetic fields could be a suitable source for treating tumors. Also, the PCR/RFLP is a simple and rapid technique representing an important progress in studies on the effect of electromagnetic spectrum on cancer.

\section{References}

1. Adair, RK (1999): Effects of very weak magnetic fields on radical pair reformation. Bioelectromagnetics. 20: 255-263.

2. Ahlbom A, Cardis E, Green A, Linet M, Savitz D and Swerdlow A (2001): Review of the epidemiologic literature on EMF and health. Environ. Health Perspect. 109: 911933.

3. Albagli O, Soudant N, Ferreira E, Dhordain P, Dewitte F, Begue A, Flourens A, Stehelin D and Leprince D (1994): A model for gene evolution of the ETS-1/ETS-2 transcription factors based on structural and functional homologies. Oncogene.9: 3259-3271.

4. Awwad MH (2003): Molecular identification of Biomphalaria alexandrina and Bulinus truncatus using PCR-RFLP of Actin gene. J. Egypt. Acad. Soc. Environ. Develop., 3 (1): 39-52.

5. Blair DG and Athanasiou M (2000): ETS and retroviruses - transduction and activation of members of the ETS oncogene family in viral oncogenesis. Oncogene.19: 6472-6481.

6. Borgens RB, Vanable JW and Jaffe LF (1977): Bioelectricity and regeneration: large currents leave the stumps of regenerating newt limbs. Proc. Natl. Acad. Sci. USA. 74: 4528-4532.

7. Davidson B, Reich R, Goldberg I, Gotlieb WH, Kopolovic J, Berner A, Ben-Baruch G, Bryne $M$ and Nesland JM (2001): ETS-1 messenger RNA expression is a novel marker of poor survival in ovarian carcinoma. Clin Cancer Res. 7: 551-557.

8. Delattre O, Zucman J, Plougastel B, Desmaze C, Melot T, Peter M, Kovar H, Joubert I, de Jong P, Rouleau G, Aurias $A$ and Thomas $G$ (1992): Gene fusion with an ETS DNA-binding domain caused by chromosome translocation in human tumours. Nature (London). 359: 162-165. 
9. Deneen B, Welford SM, Ho T, Hernandez F, Kurland I and Denny CT (2003): PIM3 Proto-Oncogene Kinase Is a Common Transcriptional Target of Divergent EWS/ETS Oncoproteins. Mol. Cell Biol. 23(11): 3897-3908.

10. Dittmer $\mathbf{J}$ and Nordheim A (1998): ETS transcription factors and human disease. Biochim Biophys Acta.1377: F1-11.

11. Foster KR (2003): Mechanisms of interaction of extremely low frequency electric fields and biological systems. Radiat. Prot. Dosimetry. 106: 301-310.

12. Fujimoto J, Aoki I, Toyoki H, Khatun $\mathbf{S}$ and Tamaya $T$ (2002): Clinical implications of expression of ETS-1 related to angiogenesis in uterine cervical cancers. Ann Oncol.;13: 1598-1604.

13. Gehl J (2003): Electroporation: theory and methods, perspectives for drug delivery, gene therapy and research. Acta Physiol. Scand. 177: 437-447.

14. Ghysdael J, Gegonne A, Pognonec P, Dernis D, Leprince D and Stehelin D (1986): Identification and preferential expression in thymic and bursal lymphocytes of a c-ETS oncogene-encoded Mr 54,000 cytoplasmic protein. Proc Natl Acad Sci U S A.83: 1714-1718.

15. Ghysdael J and Boureux A (1997): The ETS family of transcriptional regulators. In: Yaniv M, Ghysdael J., editor. In Oncogenes as transcriptional regulators. Vol. 1. Basel: Birkhäuser; 29-88.

16. Graves BJ and Petersen JM (1998): Specificity within the ETS family of transcription factors. Adv Cancer Res.75: $1-55$.

17. Hugo ER, Stewart VJ, Gast R J and Byers TJ (1992): Purification of amoeba mtDNA using the UNSET procedure. (Allen Press, Inc., Lawrence, Kansas), D7.1 .

18. Jaffe LF (1966): Electrical currents through the developing fucus egg. Proc. Natl. Acad. Sci. USA. 56: 1102-1109.

19. Kawagoe H, Potter M, Ellis $J$ and Grosveld GC (2004): TEL2, an ETS factor expressed in human leukemia, regulates monocytic differentiation of U937 Cells and blocks the inhibitory effect of TEL1 on ras-induced cellular transformation. Cancer Res. 64(17): 6091-100.

20. Kerckaert JP, Dozier C, LoucheuxLefebvre MH and Stehelin D (1989): Sst I RFLP linked to the human ETS-1 gene. Nucleic Acids Res. 15(14): 5905.
21. Kinosita $K$ and Tsong TY (1977): Formation and resealing of pores of controlled sizes in human erythrocyte membrane. Nature. 268: 438-441.

22. Lacy-Hulbert A, Metcalfe JC and Hesketh R (1998): Biological responses to electromagnetic fields. FASEB J. 12: 395420.

23. Lautenberger JA, Burdett LA, Gunnell MA, Qi S, Watson DK, O'Brien SJ and Papas TS (1992): Genomic dispersal of the ETS gene family during metazoan evolution. Oncogene.7: 1713-1719.

24. Lu J, Pazin MJ and Ravid K (2004): Properties of ETS-1 Binding to Chromatin and Its Effect on Platelet Factor 4 Gene Expression. Mol. Cell Biol. 24(1): 428-441.

25. Mucci N, Ianni A, Ursini CL, Arzani D, Bhat NK, Navarra $P$ and Romano-Spica V (2001): In vivo modulation of ETS genes induced by electromagnetic fields. In Vivo. 15(6):489-94.

26. Neumann $E$ and Rosenheck $K$ (1972): Permeability changes induced by electric impulses in vesicular membranes. J. Membr. Biol. 10: 279-290.

27. Nuccitelli R (2003): Endogenous electric fields in embryos during development, regeneration and wound healing. Radiat. Prot. Dosimetry. 106: 375-383.

28. Nuccitelli $R$ and Jaffe LF (1974): Spontaneous current pulses through developing fucoid eggs. Proc. Natl. Acad. Sci. USA. 71: 4855-4859.

29. Nunn MF, Seeburg PH, Moscovici $\mathbf{C}$ and Duesberg PH (1983): Tripartite structure of the avian erythroblastosis virus E26 transforming gene. Nature.306: 391-395.

30. Pande P, Mathur M, Shukla NK and Ralhan R (1999): ETS-1: a plausible marker of invasive potential and lymph node metastasis in human oral squamous cell carcinomas. J Pathol. 189: 40-45.

31. Rainis L, Toki T, Pimanda JE, Rosenthal E, Machol K, Strehl S, Gottgens B, Ito E and Izraeli $S$ (2005): The proto-oncogene ERG in megakaryoblastic leukemias. Cancer Res. 65(17): 7596-7602.

32. Romano-Spica V, Mucci N, Ursini CL, Ianni A and Bhat NK (2000): ETS-1 oncogene induction by ELF-modulated 50 $\mathrm{MHz}$ radiofrequency electromagnetic field. Bioelectromagnetics. 21(1): 8-18.

33. Romano-Spica V and Mucci N (2003): Biological effects of EMF exposure on ETS genes. Radiats Biol Radioecol. 43(5): 528530. 
34. Sacchi N, de Klein A, Showalter SD, Bigi G and Papas TS (1988): High expression of ETS-1 gene in human thymocytes and immature T leukemic cells. Leukemia. 2: 12-18.

35. saki H, Yukiue H, Moiriyama S, Kobayashi Y, Nakashima Y, Kaji M, Kiriyama M, Fukai I, Yamakawa $Y$ and Fujii Y (2001): Clinical significance of matrix metalloproteinase-7 and ETS-1 gene expression in patients with lung cancer. $\mathrm{J}$ Surg Res. 101: 242-247.

36. Seth A and Papas TS (1990): The c-ETS1 proto-oncogene has oncogenic activity and is positively autoregulated. Oncogene. 5: 1761-1767.

37. Seth A, Watson DK, Blair DG and Papas TS (1989): c-ETS-2 protooncogene has mitogenic and oncogenic activity.Proc Natl Acad Sci USA. 86: 7833-7837.

38. Sharrocks AD, Brown AL, Ling $\mathbf{Y}$ and Yates PR (1997): The ETS-domain transcription factor family. Int $\mathbf{J}$ Biochem Cell Biol. 29: 1371-1387.

39. Sorensen PH, Lessnick SL, LopezTerrada D, Liu XF, Triche TJ and Denny DT (1994): A second Ewing's sarcoma translocation, $\mathrm{t}(21 ; 22)$, fuses the EWS gene to another ETS-family transcription factor, ERG. Nat Genet. 6: 141-146.

40. Span PN, Manders P, Heuvel JJ, Thomas CM, Bosch RR, Beex LV and Sweep CG (2002): Expression of the transcription factor ETS-1 is an independent prognostic marker for relapse-free survival in breast cancer. Oncogene. 21: 8506-8509.

41. Sumarsono SH, Wilwon TJ, Tymms MJ, Venter DJ, Corrick CM, Kola R, Lahoud MH, Papas TS, Seth A and Kola I (1996): Down's syndrome-like skeletal abnormalities in ETS-2 transgenic mice. Nature (London). 379: 534-538.

42. Takai N, Miyazaki T, Fujisawa K, Nasu K and Miyakawa I (2000): Expression of c-ETS-1 is associated with malignant potential in endometrial carcinoma. Cancer. 89: 2059-2067.

43. Takai N, Miyazaki T, Nishida M, Nasu K and Miyakawa I (2002): c-ETS-1 is a promising marker in epithelial ovarian cancer. Int J Mol Med. 9: 287-292.
44. Teissie J (2002): Membrane destabilizations supporting electropermeabilization. Cell Mol. Biol. Lett. 7: 96-100.

45. Teitell MA, Thompson AD, Sorensen PH, Shimada H, Triche TJ, Denny CT (1999): EWS/ETS fusion genes induce epithelial and neuroectodermal differentiation in NIH 3 T3 fibroblasts. Lab Invest. 79(12): 1535-1543.

46. Tokuhara K, Ogata Y, Nakagawa $M$ and Shirouzu K (2003): ETS-1 expression in vascular endothelial cells as an angiogenic and prognostic factor in colorectal carcinoma. Int Surg. 88: 25-33.

47. Topol LZ, Tatosyan AG, Ascione R, Thompson DM, Blair DG, Kola I and Seth A (1992): C-ETS-1 protooncogene expression alters the growth properties of immortalized rat fibroblasts.Cancer Lett. 67: 71-78.

48. Wang H, Zheng J, Wang YP, Yang Y and You JF (2005): Molecular detection of EWS-ETS fusion transcripts and their clinicopathologic significance in Ewing's sarcoma/peripheral primitive neuroectodermal tumor. Chin Med J (Engl). 118(16): 1323-1329.

49. Watson DK, McWilliams-Smith MJ, Nunn MF, Duesberg PH, O'Brien SJ and Papas TS (1985): The ETS sequence from the transforming gene of avian erythroblastosis virus, E26, has unique domains on human chromosomes 11 and 21: both loci are transcriptionally active. Proc Natl Acad Sci USA. 82: 7294-7298.

50. Weaver JC (2003): Electroporation of biological membranes from multicellular to nano scales. IEEE Trans. Dielectr. Electr. Insul. 10: 754-768.

51. Weaver JC, Vaughan TE and Martin GT (1999): Biological effects due to weak electric and magnetic fields: The temperature variation threshold. Biophys. J. 76: 3026-3030.

52. Weaver JC, Vaughan TE and Astumian RD (2000): Biological sensing of small field differences by magnetically sensitive chemical reactions. Nature. 405: 707-709.

53. Zimmermann U, Pilwat $G$ and Riemann F (1974): Dielectric breakdown of cell membranes. Biophys. J. 14: 881-899. 
دراسات بيولوجية جزيئية على تأثير المجالات الكهرومغناطيسية على الجين

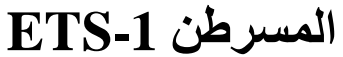

أماني عبد المنعم تهامي* ـ محمد حسين عواد*** ـ ناهد محمد الأبيض **** ـ ـ ـ

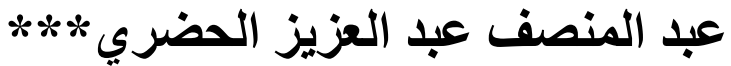

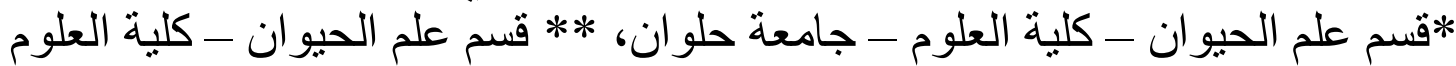

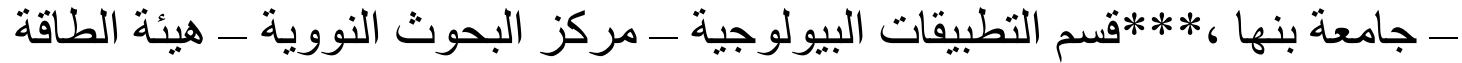

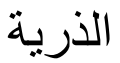

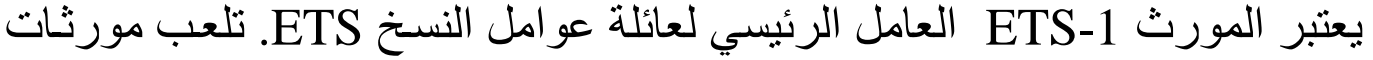

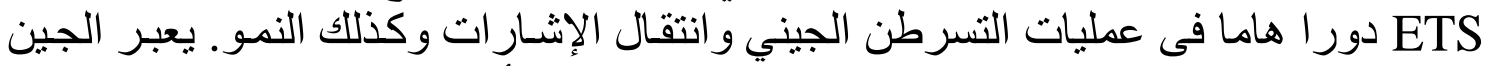
ETS-1

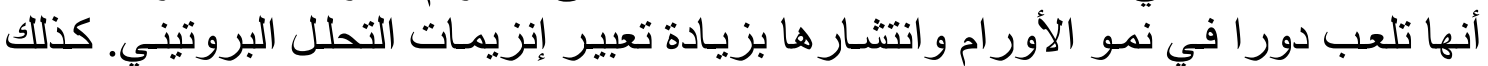

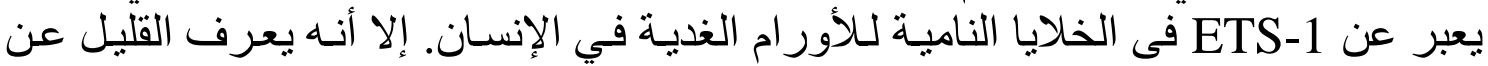
التداعيات الوظيفية لهذه الملاحظة.

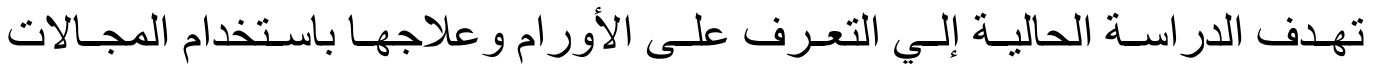

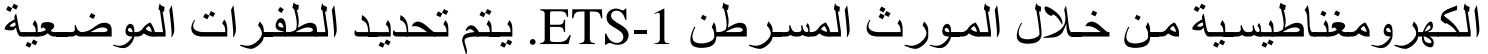

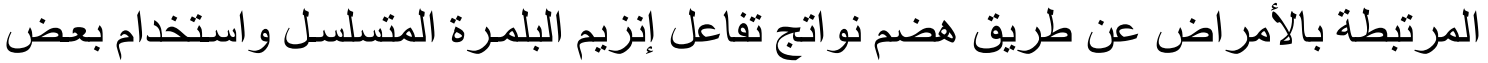
الإنزيمات المحددة (SacII وAatI, BanI, BanII, DraI, DraIII, EaeI, PstI ) و التي ينشأ اختلاف في أنماط أطو ال القطع الناتجة عن الهضم (RFLP) و التي تثير إلى (BA) الطفرة موضع الدراسة.

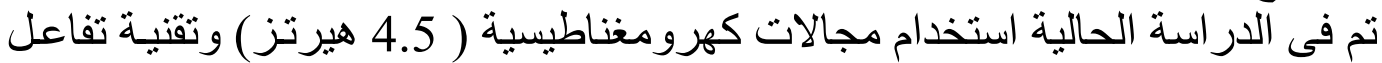

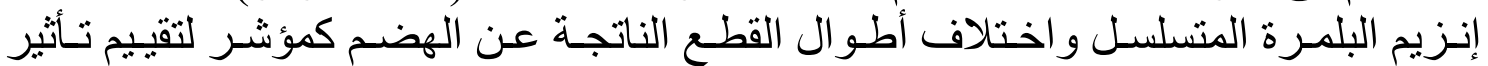

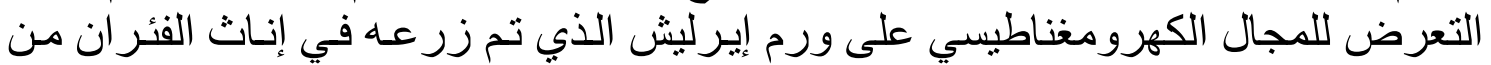

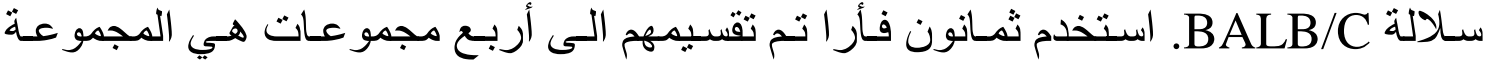

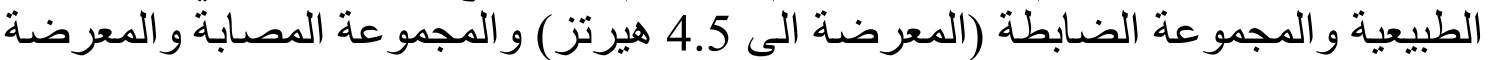

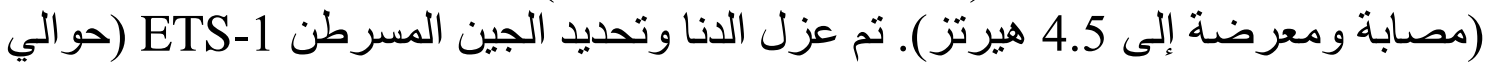

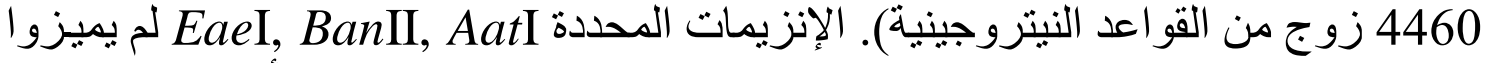

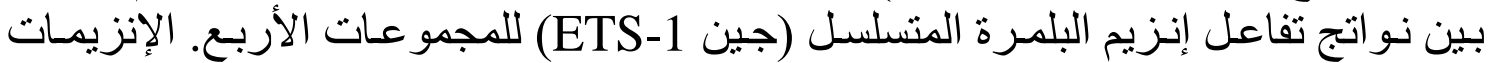
DraI, BanI, PstI, SacII, DraII

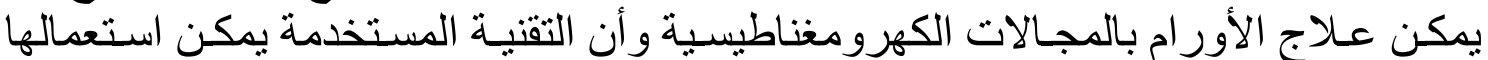

